\title{
Pediatric presentation of pulmonic effusion secondary to influenza
}

\author{
Norma L. Cooney • Derek R. Cooney • Brian Kloss
}

Received: 2 June 2009 / Accepted: 13 June 2009 /Published online: 1 August 2009

(C) Springer-Verlag London Ltd 2009

A previously healthy 13-year-old male presented with a 10-day history of intermittent fevers. He had a several-day history of productive cough with nausea and vomiting and had been treated for dehydration 4 days previously. No chest X-ray was obtained. On the second visit to the ED, the patient was markedly hypotensive (80/40), tachycardic, and febrile at $104.9^{\circ} \mathrm{F}$. On exam, his mentation was slow. The patient's extremities appeared mottled and cyanotic. He had decreased breath sounds in the left lung fields. Chest X-ray showed left lower lobe pneumonia with a large left pleural effusion (Fig. 1). Laboratory tests showed marked leukocytosis with a left shift. Blood cultures were negative, but nasopharyngeal swabs were positive for influenza A $\mathrm{H} 1$ and $\mathrm{H} 3$.

The etiology of pneumonia with extensive pleural effusion includes bacteria, with $S$. pneumoniae, $S$. aureus and $H$. influenzae being the most frequent pathogens, followed by viral agents, atypical bacteria, and, rarely, malignancy. Influenza A and RSV are the most common causes of viral pneumonia, followed by adenovirus, parainfluenza virus, and

\footnotetext{
N. L. Cooney $(\bowtie)$

Department of Emergency Medicine,

SUNY Upstate Medical University,

750 East Adams Street,

Syracuse, NY 13210, USA

e-mail: cooneyn@upstate.edu

D. R. Cooney $\cdot$ B. Kloss

Department of Emergency Medicine,

SUNY Upstate Medical University,

EMSTAT Center/550 East Genesee,

Syracuse, NY 13202, USA

D. R. Cooney

e-mail: cooneyd@upstate.edu

URL: http://www.upstate.edu/emergency/residency/fellowship/

emsdm.php

B. Kloss

e-mail: klossb@upstate.edu
}

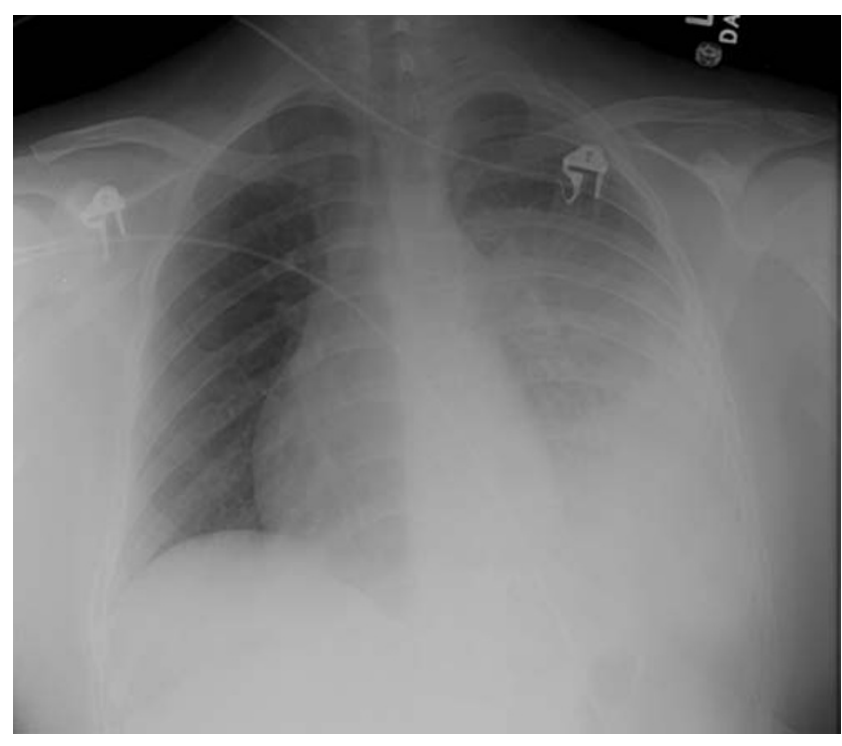

Fig. 1 Left lower lobe pneumonia with large pleural effusion

influenza B [1]. Pneumonia occurs in a minority of patients with influenza (3-16\%) [2]. Pleural effusion, while likely to develop in at least $40 \%$ of patients with bacterial pneumonias [3], is a rare complication of influenza pneumonia [2]. Bacterial coinfection is the most common complication of influenza pneumonia and occurs in up to $20 \%$ of cases [2]. This child had a high probability of having a bacterial coinfection. His late presentation precluded treatment with adamantanes or neuraminidase inhibitors.

\section{References}

1. Marcos MA, Esperatti M, Torres M (2009) Viral pneumonia. Curr Opin in Infect Dis 22:143-147

2. Lahti E, Peltola V, Virkki R, Ruuskanen O (2006) Influenza pneumonia. Ped Infect Dis J 25(2):160-164

3. Sinaniotis CA, Sinaniotis AC (2005) Community-acquired pneumonia in children. Curr Opin in Pulm Med 11:218-225 